\title{
From Bismarck to Beveridge: the other pension reform in Spain
}

\author{
J. Ignacio Conde-Ruiz' ${ }^{1}$ Clara I. González ${ }^{2}$
}

Received: 10 April 2016 / Accepted: 5 August 2016 / Published online: 30 August 2016

(C) The Author(s) 2016. This article is published with open access at Springerlink.com

\begin{abstract}
Ageing is the major challenge for the PAYG pension systems in developed countries. Most of them are undergoing reforms in order to adapt to the new demographic reality. The package of reforms implemented includes increasing the retirement age, reducing the replacement rate, or introducing a sustainability factor linking pension to life expectancy. The aim of this paper is to analyse the potential consequences of a different type of reform that is at a very incipient stage in Spain but that could have a significant impact if it were fully implemented. This reform, called 'silent reform' because it is imperceptible to citizens in its early stages, basically consists in increasing maximum pensions in line with inflation instead of wage or productivity growth. This policy is reducing the replacement rate only for high earning workers and increasing the redistributive component of the system. This paper is the first to quantify and evaluate the potential consequences of this type of reform in Spain. We have used an accounting model with heterogeneous agents and overlapping genera-
\end{abstract}

The research on which this article is based won a Second Prize at the 2011 FIPROS Awards (TIN/731/2011). The authors thank Michele Boldrin, Vincenzo Galasso, Juan Francisco Jimeno, José Manuel Marqués, as well as anonymous referees and participants during the seminar at Banco de España for helpful comments and discussions. They also appreciate the support received from the Ministry of Science and Technology throughout the project with Ref. ECO2014-59491-P. The results and views expressed in this document are the sole responsibility of the authors and, therefore, do not necessarily reflect those of their institutions of affiliation, the Banco the España or the Eurosystem.

J. Ignacio Conde-Ruiz

nacho.conderuiz@gmail.com

Clara I. González

gonzalez.claraisabel@gmail.com

1 Universidad Complutense de Madrid and Fundación de Estudios de Economía Aplicada FEDEA, c/ Jorge Juan, 46, 28001 Madrid, Spain

2 Banco de España, c/ Alcalá 48, 28014 Madrid, Spain 
tions in order to project pension expenditure for the next six decades. The results show that this type of reform could potentially contain future expenditure but at the cost of changing the nature of the pension system from a contributory or Bismarckian-type system into a pure redistributive pension system or Beveridgean-type one.

Keywords Ageing - Spanish pension system · Reform · Sustainability · Accounting projection model

JEL Classification H55 $\cdot$ J11 $\cdot$ J26

\section{Introduction}

There is no doubt that the population ageing is threatening the financial sustainability of Pay-As-You-Go pension systems. In the last decades, many countries have undertaken major reforms and others are now undergoing similar processes. Spain finds itself in this latter case, and several studies have shown that, in the absence of reforms, pension expenditure would increase in the next four decades, accelerating from 2035 onwards (European Commission 2009a; MTIN 2008; Jimeno et al. 2008; Diaz-Saavedra 2005; de la Fuente and Doménech 2009; Rojas 2005; Sanchez-Martin and Sanchez-Marcos 2010; Alonso and Herce 2003; Herce et al. 2009). The changes approved in Spain in 2011, which included increasing the retirement age from 65 to 67, among others, together with the introduction of the Sustainability Factor in 2013, are the most significant reforms that have been made in decades.

Despite the last two major reforms of the Spanish pension system, the ageing process is so intense that it will be impossible to prevent the replacement rate from decreasing at least 20 to 25 percentage points moving from the current 74 to $50 \%$ in the next decades. ${ }^{1}$ As a result, a public debate has arisen, in which it is argued that it would be fairer if the inevitable fall in the replacement rate were mainly focused on pensioners with the highest pensions.

Therefore, if this type of reform were to be implemented, it would change the basis of the Spanish pension system from a contributory system (or Bismarckian) to a universal pension system (or Beveridgean). Currently, both types of pension models exist in Europe. Bismarckian systems are designed to provide a sufficient retirement income for all workers: from the low skilled to the highly skilled. In contrast, the Beveridgean pension system aims to ensure a minimum pension and, as a result, requires lower contributions, leaving room for the middle classes to add to their pension pot with private savings. Indeed, countries with a Beveridgean system have an average pension expenditure of $6 \%$ of GDP, while countries with a Bismarckian pension system have an average expenditure of more than $10 \%$ of GDP.

In view of the above, how could this type of reform be implemented? In the case of Spain, this would be feasible if some key parameters of the pension system were

\footnotetext{
1 The changes approved in 2011 only solved about one-third of the expected increase in pensions expenditure without reforms, as it was highlighted in several studies [see MEH (2011), Banco de España (2010), Fuente and Doménech (2013) and Conde-Ruiz and González (2013)].
} 
modified - in particular the value of the maximum and minimum pension, as well as the upper and lower limit of the contribution base. This would result in major changes in the redistribution and the overall generosity of the system, which is defined as the ratio between average pension and productivity. In fact, a low intensity reform of this type has been carried out in Spain. Some experts have named it the 'silent reform' of the pension system due to the fact that it is almost imperceptible to voters in the initial phase. More specifically, the key measures in this kind of reform are: (1) adjusting pensions in line with inflation instead of wage growth, and (2) setting a cap to the maximum retirement benefit an individual may receive (maximum pension) and indexing it to inflation. In a period of economic growth, these measures would imply an increase in the number of retired individuals whose pensions would be limited due to the maximum pension limit. For this reason, any of these two measures could reduce future pension expenditure because they would break the link between benefits and wage growth.

The aim of this article is to quantify the potential consequences of this hypothetical reform, which has been widely discussed and studied in theoretical terms in Spain [amongst others Boldrin et al. (2000), Jimeno (2002), Alonso and Herce (2003), Conde-Ruiz and Alonso (2004) and Conde-Ruiz and Jimeno (2004)]. To date, there are no studies quantifying its implications, and this paper is the first to analyse its hypothetical impact on the Spanish pension system.

The main results of the paper show that if this type of reform were to be fully implemented, it would change the basis of the Spanish pension system by transforming it into a universal pension system (or Beveridgean). We quantified how the intragenerational redistribution element in the pension system would increase. Moreover, we show the important implications that this sort of reform would have on reducing future expenditure, as well as on the overall generosity of the system. In order to evaluate the potential of the reform in the sustainability of the Spanish pension system we compared its effects with those of the 2011 reform, which, among other changes, increased the retirement age from 65 to 67.

The idea of converting the Bismarckian Spanish pension system into a Beveridge one is starting to enter public debate. The financial crisis in Spain has exacerbated income inequality, not only due to significant wage devaluation, but also to a high increase in the long-term unemployment rate. In this respect, Conde-Ruiz and Profeta (2007) have provided a positive theory on why a Bismarckian or a Beveridgean system may arise. They show that income inequality represents the key determinant in social security design and suggest that Beveridgean systems may be supported by a voting coalition between low-income individuals, who favour its redistributive aspect, and high-income individuals, who support the reduced size of the Beveridgean system, which allows them to make more use of private provisions.

This paper is set up as follows: Sect. 2 discusses the role of the upper limits to contribution bases and pension benefits and the institutional aspects of the Spanish pension system. The methodology used in our simulations is presented in Sect. 3.1. Next, the results related to individual pensions are collected in Sect. 3.2, regarding the percentage of new pensions that are affected by both the upper cap and the amount to which the pension is limited. The implications regarding the sustainability of the 
pension system are discussed in Sect. 3.3. In Sect. 3.4, the consequences for the nature of the system are examined. Finally, we draw our conclusions. Additional results are presented in the Appendix, together with the rules for calculating retirement pensions in Spain.

\section{Bismarck vs Beveridge}

If we examine PAYG pension systems worldwide, we can see that different degrees of intragenerational redistribution exist and that there are no completely pure Bismarckian systems. There are a number of papers, such as Disney (2004) or Conde-Ruiz and Profeta (2007), that have classified different pension systems in the world as either Bismarckian or Beveridgean. ${ }^{2}$ Bismarckian systems are designed to provide a sufficient retirement income for all workers: from the low skilled to the highly skilled. In contrast, the Beveridgean pension system aims to ensure a minimum pension and, as a result, requires lower contributions, leaving room for the middle classes to add to their pension pot with private savings.

As shown by Disney (2004) and Conde-Ruiz and Profeta (2007), each system has specific and different characteristics ${ }^{3}$ which were present at the very beginning of both systems. On the one hand, the Beveridgean system has historically been associated with lower pension expenditure in terms of GDP compared to Bismarckian systems. On the other hand, countries with a Beveridgean system tend to have more developed private pension systems and the use of private pension plans is more widespread. The aforementioned differences can be seen in the following Fig. 1, in which several countries are classified by type of pension system according to Disney (2004): Bismarckian (BI with a diamond) or Beveridge (BE with star), together with the public and private expenditure of each country. It can be observed how Beveridgean countries spend about $6 \%$ of their GDP on public pensions, while Bismarckian countries spend on average more than $10 \%$ of their GDP. In contrast, the reverse occurs when analysing expenditure on private pensions. Countries with a Beveridgean system spend much more on private pensions than their Bismarckian counterparts: $3.5 \%$ compared with just less than $1 \%$.

In the case of the Spanish pension system, it is a contributory or Bismarckian system and it has a certain degree of intragenerational redistribution through its minimum pensions. The Social Security system establishes maximum and minimum limits to the contributions and pensions, which are set each year by the government. And the relation between the lower and upper limits of both pensions and contribution bases is one of the key factors in determining the future development of the system.

\footnotetext{
2 To classify a pension system as either Bismarckian or Beveridge, Conde-Ruiz and Profeta (2007) and Disney (2004) defined a Bismarckian index using the correlation between wages and pension received.

${ }^{3}$ A more recent classification of countries according to the Bismarkian or Berverdigean nature of the pension system Krieger and Traub (2013) gives almost the same result as Disney (2004).
} 


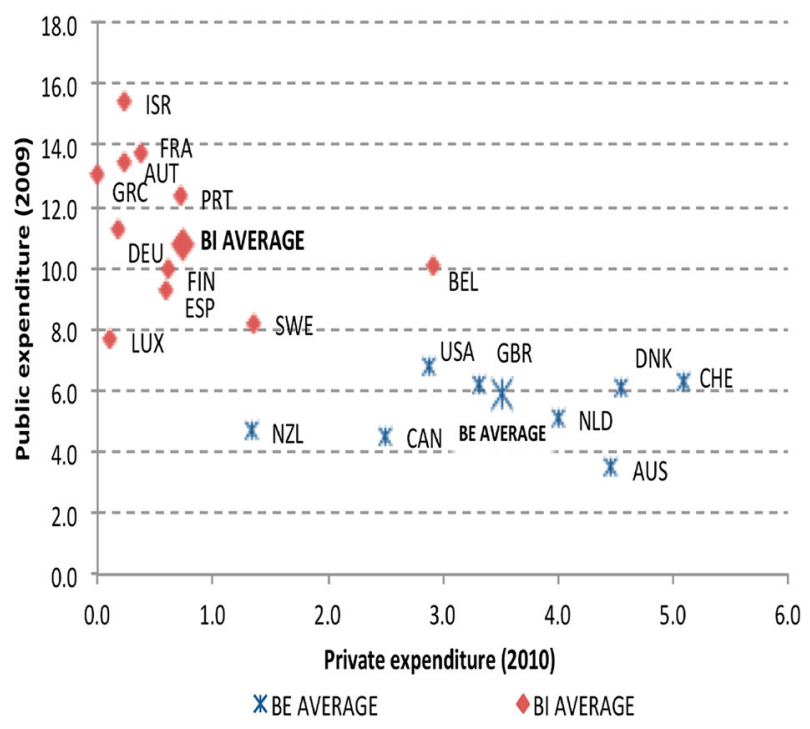

Fig. 1 Public and private pension expenditure in Bismarckian and Beveridgean countries (\% of GDP). Source: OECD (2013) and Disney (2004)

\subsection{The mechanism of the 'silent reform' of the pension system}

The pension system in Spain ${ }^{4}$ seemed not to have undergone any major reform in the two decades before the reform that was approved in 2011,5 in which the retirement age was increased to 67 among other changes, and the introduction of the Sustainability Factor designed in year 2013. ${ }^{6}$

However, even during the period without reforms, and according to some experts, the Spanish social security system was undergoing changes caused by the development of some of the system's key parameters, including the maximum and minimum limits on pensions and contributions. The pension policy over the last 15 years, as discussed in more detail in Sect. 2.2, shows two clear trends: (1) the value of minimum pensions has increased in real terms, while maximum pensions have been adjusted with inflation-

\footnotetext{
${ }^{4}$ The Spanish social security system is a PAYG system, and is defined as one in which a retired worker receives a pension that is dependent on their employment history (wages, years of contribution to the system and retirement age). In 2013, the Sustainability Factor was designed and approved (Law 23/2013 of 23 December, Reguladora del Factor de Sostenibilidad y del Índice de Revalorización del Sistema de Pensiones de la Seguridad Social) and will come into force in 2019. It will take into account the increase in life expectancy at age 67 in the calculation of the initial retirement pension.

5 Prior to the 2011 reform, the two most relevant reforms took place in 1997 and 2002. In 1997 eligibility and the reference wage were extended to 15 years and the replacement rate was changed. With the 2002 reform early retirement was allowed at 61 for workers who had not contributed before 1967 but who had a minimum of 30 years of contributions. It also introduced changes to the penalization coefficient linked with age of retirement. See more details in Appendix A.

${ }^{6}$ See Diaz-Gimenez and Diaz-Saavedra (2014) and Sanchez-Martin (2014) for an analysis of the impact of this reform.
} 
maintaining their value in real terms but reducing their purchasing power in relation to the average wage; and (2) minimum contribution bases have been reduced in real terms, while the upper limit of contributions has remained almost constant in real terms.

The slight modification of these parameters has not received much attention in the media or in political arenas because they have been regarded as secondary factors to the financial sustainability of the pension system. However, as we will see in the paper, persistent changes to these parameters will generate significant modifications in the distributive structure of the social security system and would inevitably have an important impact on both the policy on pensions and their financial sustainability. This is why it has been called a 'silent reform' [amongst others, Boldrin et al. (2000), Jimeno (2002), Alonso and Herce (2003), Conde-Ruiz and Alonso (2004) and Conde-Ruiz and Jimeno (2004)]. It substantially affects the nature of the social security system without reforming any of the criteria that are considered to be the most important ones, such as the contribution rate, retirement age, contribution bases, pension formulae, etc.

Despite the fact that the general population would not notice the impact of this type of reform at its incipient stage, the consequences would be evident in time. Let us look at a scenario in which there is a positive growth rate in productivity and all the pensions (including the maximum pension) are adjusted in line with inflation. If wages (and all contribution bases including the maximum limit) grow steadily at the rate of productivity, but the maximum pension threshold is not adjusted in line with wages, then the replacement rate (ratio pension / average wage) will decrease for individuals entitled to the maximum pension - and the ratio (average pension /average productivity) of the system as a whole will also decrease. Therefore, in time, pension value would stop increasing at the same rate as wages and would eventually reach the cap. Consequently, the number of people receiving the maximum pension would increase over time. Moreover, there would be a decrease in the ratio between the average pension and average productivity. Nowadays the number of individuals who retire with a maximum pension is around $3 \%$. If this mechanism were taken to its extreme, with wages growing at the same rate as productivity (and therefore contributions as well), the number of individuals eligible to receive the maximum pension would also increase, although the value of the pension would remain constant in real terms.

This result would imply that this sort of reform would transform the system from a contributory or Bismarckian system (such as the current Spanish system in which pensions depend on past contributions), into a Beveridge system or pure redistributive pension system, in which all individuals receive the same pension regardless of their contributions. This would mean that the very nature of the pension system would change without anyone realising. This critical aspect will be discussed in detail in Sect. 3.4. The increasing gap between the limits would also affect the sustainability of the system, and, although more individuals would receive the maximum pension the generosity of the system would decrease in time because the maximum pension 
value would remain constant in real terms. This means that not only would the nature of the system change, but it would also have important effects on containing pension expenditure, as we will see in the next section.

\subsection{Institutional elements}

The Spanish Social Security system establishes maximum and minimum limits to the contributions and pensions, which are set each year by the government. Employers and employees contribute a percentage of the worker's wages to the social security system. ${ }^{7}$ Contributions are limited by both a floor $b_{\min }$ and a ceiling $b_{\max }$. The contribution base represents the fraction of labour earnings subject to social security contributions and it is linked to wage $\omega$ :

$$
b_{t}=\left\{\begin{array}{ccc}
b_{\min } & \text { for } & \omega_{t}<b_{\min } \\
\omega_{t} & \text { for } & b_{\min } \leq \omega_{t} \leq b_{\max } \\
b_{\max } & \text { for } & \omega>b_{\max }
\end{array}\right.
$$

At the same time, the Spanish pension system is characterised by having a minimum (i.e. $p_{\min }$ ) and a maximum retirement pension (i.e. $p_{\max }$ ). The minimum pension is intended for those individuals who are eligible to receive a contributory pension but whose contributions are below a certain threshold. This floor depends on the type of pension (retirement, widowhood, disability or orphanage), age (older or younger than 65) and personal circumstances (with or without dependent spouse), and, moreover, there is also an earnings limit. However it does not depend on the number of years of contributions. The maximum pension limits the amount that individuals with higher pensions would receive. ${ }^{8}$ The contributory pension that an individual receives can be expressed as:

$$
P=\left\{\begin{array}{ccc}
p_{\min } & \text { for } & p<p_{\min } \\
p & \text { for } & p_{\min } \leq p \leq p_{\max } \\
p_{\max } & \text { for } & p \geq p_{\max }
\end{array}\right.
$$

These two elements have evolved differently over time. The minimum pension value has historically increased in real terms (with significant increases in the years before the start of the crisis). In contrast, the maximum pension value has remained fairly constant in real terms over the past two decades, due to its rising in line with inflation. Figure 2 shows the trend of the upper limits for both pensions and contributions since $1982,{ }^{9}$ and the following points are relevant for the simulations carried out in this article: (1) the maximum contribution base has historically increased with inflation at the same time that the different professional categories

\footnotetext{
7 The statutory contribution rate for common contingencies is $28.3 \%$, of which $4.7 \%$ is paid by the worker and $23.6 \%$ by the company.

8 It was established in the year 1984 and it is the same for all pension types and personal circumstances.

9 For the evolution of the lower limits for contribution bases and pensions, see Conde-Ruiz and González (2016).
} 
(a)

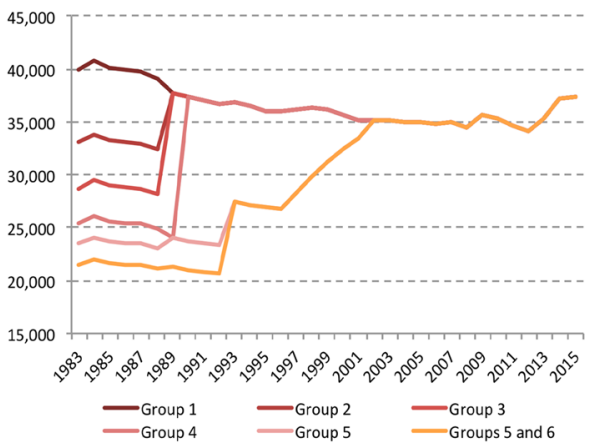

(b)

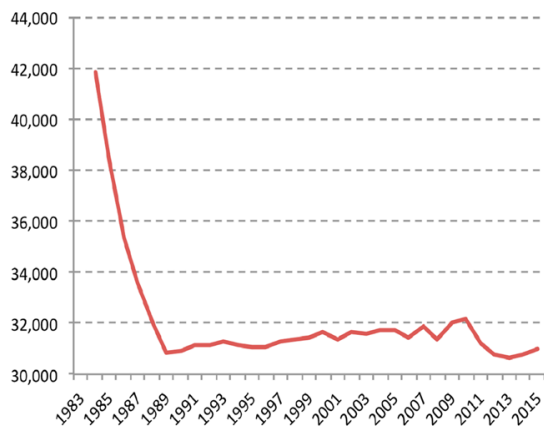

Fig. 2 Maximum contributions and retirement pensions (euros/year real terms 2006, 1983-2015). a Contribution base. b Retirement pension. Source: Ministry of Employment and Social Security and INE

were grouped together, remaining steady in real terms from the year 2002 onwards. It has increased since 2013; (2) the upper limit for the maximum retirement pension was established in 1984 and it remained constant (in nominal terms) between 1984 and 1988. At the same time the prices increased considerably, so the maximum pension dropped a $23.4 \%$ in real terms. Later, it increased in line with inflation up until 2010 but has not followed the trend of real wages. It has dropped in real terms since 2011.

In a contributory system, the relation between contributions and pensions (maximum and minimum values) is a key element of the intragenerational redistribution of the pension system and both ratios should be stable and equal to 1 . For individuals with complete working histories who always had the maximum (or minimum) contribution base the corresponding pension should be equal to the maximum (or minimum) limit. Figure 3 shows the evolution, since 1984, of the ratio between the minimum pension and contribution base values (pension/contribution base) and the same ratio between the maximum values. The maximum pension has remained steadily below the maximum contribution cap (ratio less than 1) in the last ten years. Since 2000, the minimum pension has grown above the minimum contribution limit (ratio greater than 1). In 2015, ${ }^{10}$ the maximum pension was $17.1 \%$ lower than the maximum contribution base, while the minimum pension was $20.7 \%$ higher than the minimum contribution base. This first piece of evidence points towards the system already bearing the effects of a greater difference between the maximum pension and the maximum contribution base. This means that those workers who contribute continuously the maximum amount would receive a lower pension from the system than they should according to their contributions, and vice versa for those who contribute the minimum.

\footnotetext{
10 In 2013, the maximum contribution base rose $5 \%$ and the maximum pension $1 \%$. In 2014 the maximum contribution increased by the same amount as in 2013, and all pensions including the maximum limit grew by $0.25 \%$.
} 


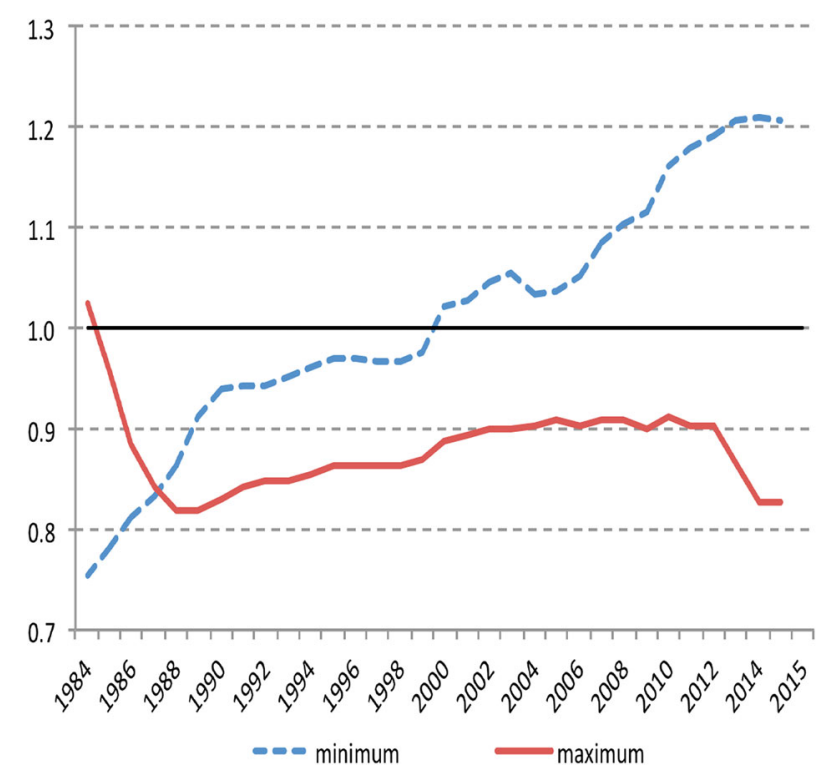

Fig. 3 Ratio pension to contribution base-minimum and maximum (1984-2015). Source: Ministry of Employment and Social Security and own elaboration

\section{From Bismarck to Beveridge: the case of Spain}

The aim of this paper is to analyse the potential effects of a pension reform through changes to the maximum limits (contribution bases and pension values) in the coming decades up until 2070 . We will quantitatively study the potential consequences to the Spanish pension system of different growth rates between the maximum contribution base and the maximum pension benefit. In particular, we will look at the potential effects of such a reform regarding sustainability, as well as its ability to alter the nature of the pension system, i.e. to transform a contributory or Bismarckian pension system (the current Spanish pension system) to a Beveridgean system. The model used is an accounting model with heterogeneous agents and overlapping generations in order to project revenues and expenditures of the pension system for the next six decades.

As seen in the previous section, maximum and minimum limits are fixed each year by the government. Although it is not possible to capture exactly how the effects of these decisions will evolve in time, we are going to set out different possible scenarios. First of all, we will assume that both the upper and lower caps for contributions and pensions will grow at the same rate as productivity. This scenario will be called 'scenario 1 or neutral', i.e. where the mechanism explained in Sect. 2.1 does not apply. We will also examine three alternative scenarios in which the growth rate of the maximum pension benefit is lower than the productivity rate. Specifically:

- two 'middle scenarios': the maximum contribution base grows alongside productivity, as in the neutral scenario, but the maximum pension increases 50 and $30 \%$ 
of the productivity growth, respectively. They are called scenario 2 or $(1,0.5)$ and scenario 3 or $(1,0.3)$, respectively.

- a 'scenario 4 or extreme scenario' [or $(1,0)$ ]: the maximum contribution grows at the same pace as productivity, as in the neutral scenario, but the maximum pension benefit is not indexed with productivity and remains constant in real terms.

The methodology used for the projections is described in the next section and in Sect. 3.2 we present the results obtained concerning the impact of the reforms on: (1) the number of new pensions that are capped and (2) the quantity by which the new pensions are limited. In order to analyse the impact on individual pensions we will focus on pensions obtained by employees (or under the General Regime) who retire at the legal age of 65 , because it is the most affected group by this sort of reform. ${ }^{11} \mathrm{We}$ will also discuss their possible effects on the sustainability of the pension system (Sect. 3.3) prior to the 2011 reform (in this case we also consider the workers who retire early). This will allow us to analyse the potential of this type of reform by comparing the results from 2011 obtained in Conde-Ruiz and González (2013) with the same model, the same methodology and the same demographic scenario. ${ }^{12}$ Finally, we will highlight the implications of the system through the analysis of its generosity and the replacement rate (Sect. 3.4).

\subsection{Projection methodology}

The developed model is an accounting projection model with heterogeneous agents and overlapping generations, used for the projection of revenues and expenditures of the Spanish social security system. It includes a high degree of individual distinction (by age, gender, nationality and level of education). ${ }^{13}$ The simulation period starts in 2006 and runs over six decades up to 2071.

Individuals live for 17 periods where every period corresponds to five calendar years. They enter the economy at the age of 15 and live, at most, until the age of 100. The maximum potential working life of an individual is therefore ten periods (from age 15 to 64), as 65 is the legal retirement age. The maximum period of potential life in retirement (for individuals retiring at 65) is seven periods. Individuals are classified by age and also by gender (male and female), educational level (primary school, secondary school and tertiary education), and by country of origin (natives and immigrants). So, there are a total of 12 different groups of individuals and each one is divided into 17 subgroups according to age.

\footnotetext{
11 Appendix B provides details of these results in case of early retirement between 61 and 64 and for self-employed individuals.

12 It is important to point out that it is not appropriate to compare our results with the impact of the 2013 reform as generated by other authors (MINECO 2014; Diaz-Gimenez and Diaz-Saavedra 2014; SanchezMartin 2014) because they use a methodology and demographic scenario different to ours.

13 Model developed in González (2013) and used in Gonzalez et al. (2009) to analyse the impact of the migration phenomena in the Spanish pension system and in Conde-Ruiz and González (2013) to evaluate the pension reform approved in 2011.
} 
The model includes a great deal of detail regarding the Spanish pension system, ${ }^{14}$ which allows us to differentiate between employees contributing to the general system (Régimen General de la Seguridad Social) and self-employed workers contributing to the special self-employment scheme (Régimen Especial de Trabajadores Autónomos), which are analysed separately. The total number of qualifying years or years of contributions, the contribution bases and the retirement age are elements that determine the calculation of an individual's pension and are all taken into account.

The simulation strategy is developed in three main phases. Firstly, the population projection based on the Cohort Component Population Projection Method with the aforementioned heterogeneous agents is employed. Secondly, the reconstruction and projection of employment history is carried out using data from the Continuous Sample of Working Histories of Social Security (Muestra Continua de Vidas Laborales, MCVL), ${ }^{15}$ micro data from the Labour Force Survey (LFS), and the corresponding data from the National Statistical Institute of Spain (Instituto Nacional de Estadística de España, INE) to obtain the transition probabilities for five different working situations (employed, self-employed, unemployed, disabled and another situation of inactivity) according to the different heterogeneous agents considered. During their working lives, individuals contribute to the system. Once they retire they receive a retirement pension that depends on the terms of their employment history. We also take into account that they may generate a widow's pension when they die. The calculation of the pension expenditure is the third stage of the projection process.

STAGE 1: Demographic projection The first phase of the model consists on the projection of the population up to 2071 . To calculate this projection we employ the

\footnotetext{
14 The projection model contains individual heterogeneity and institutional detail that is a noteworthy characteristic of this model in comparison with other models used to project pension expenditure in Spain. Firstly, it can distinguish age, sex, educational level and nationality [versus other models, such as in Jimeno (2003), Diaz-Saavedra (2005), Sanchez-Martin and Sanchez-Marcos (2010), Jimeno et al. (2008), DiazGimenez and Diaz-Saavedra (2006), Diaz-Gimenez and Diaz-Saavedra (2009), Sanchez-Martin (2001) and Sanchez-Martin (2010)]. Secondly, as far as we are aware, our model is the first to consider five different working situations for any given individual (employed, self-employed, unemployed, disabled and inactive) versus papers by Jimeno (2003), Alonso and Herce (2003), Sanchez-Martin (2001), Sanchez-Martin (2010), Diaz-Saavedra (2005), Diaz-Gimenez and Diaz-Saavedra (2006), Diaz-Gimenez and Diaz-Saavedra (2009), Rojas (2005) and Sanchez-Martin and Sanchez-Marcos (2010). Moreover, this is one of few models that employs data gathered from the administrative database called Continuous Sample of Working Histories (Gil et al. 2008; Moral-Arce et al. 2008; Herce et al. 2009 also employ this database) to predict accurately contributions in accordance with individual heterogeneity. It includes detail at the institutional level that allows us to obtain precise data on pension value and incorporates widow's pensions. The model also takes into account other important elements in the system such as the upper and lower cap of both contributions and pension benefits; key elements that are being examined in this paper. Other articles that have taken this into account to some extent include Jimeno (2003), Sanchez-Martin and Sanchez-Marcos (2010), DiazSaavedra (2005), Diaz-Gimenez and Diaz-Saavedra (2006), Diaz-Gimenez and Diaz-Saavedra (2009) and Moral-Arce et al. (2008).

15 The Continuous Sample of Working Histories is a database created by the Spanish Ministry of Labour and Social Affairs that contains records of the working and pension histories of $4 \%$ of the people who, at any time in the corresponding wave, had a registered record with the social security system, either as contributors or as pensioners. For more details, see Seguridad Social (2006) and Argimón and González (2006).
} 
Cohort Component Population Projection Method. The demographic situation in the year 2006 is taken as the starting point in order to be consistent with data from the database Muestra Continua de Vidas Laborales (MCVL) for the same year. We adopt the overall demographic hypotheses regarding life expectancy (and corresponding survival probability) and fertility rates released by the Spanish National Institute of Statistics (INE) in its long-term projection scenario up to 2051 [see, INE (2005)]. For the period 2051-2071 we assume a stable development of the three variables from 2051 onwards. The total figures projected by the INE for total number of births and net migration flows are categorised by gender, age and nationality. Moreover, we have taken into account the level of education of future generations as it constitutes an important factor regarding employability. We assume that all the new generations will reach the same level of education as the most educated individuals so far, (i.e. those born in 1975 and who were 32 years old in 2007). The implications of this assumption mean that the percentage of the labour force with only an elementary level of education will decrease and that the percentage of university graduates will increase by ten points by 2060 [see, González (2013)].

STAGE 2: Projection of work history We project both revenue and expenditure of the social security system taking into account the assumptions about labour force participation, employment and productivity until the year 2051 in line with the macroeconomic scenario used by Spain's Ministry of Economy and Finance joint exercise with the European Commission for long term pension expenditure projection (European Commission 2009a)]. From the year 2051 onwards it is assumed that forecasts will remain constant until 2071. Our underlying assumption is that the relevant legislation will not change; therefore the contributions will grow parallel to wages, which in turn will grow at the same rate as labour productivity.

Labor productivity growth rate is the main element of the macroeconomic scenario. In the long run, the growth in labor productivity (output per hour worked) broadly coincides with TFP growth divided by the labor share (set at 0.65). In particular, the EPC assumptions establish that TFP growth rates (for each country) will converge to a long-term historical average TFP growth rate recorded in the EU, of $1.1 \%$. However, as a sensitivity exercise, we are going to consider a new scenario for the productivity growth rate where the growth rate is $50 \%$ lower in the short run and $12 \%$ lower in the long run. ${ }^{16}$ As we will see along the paper, the effects of the 'silent reform' would be minor when we consider this alternative scenario with a lower productivity growth rate.

The labor market scenario basically implies an evolution towards a full employment situation [unemployment rate of $6.2 \%$ and employment rate (15-64) close to $73 \%$ ]. Women and older workers are responsible of the main increases in the employment rate (Table 1).

\footnotetext{
16 This scenario for the labor productivity growth rate is consistent with the latest assumptions in European Commission (2015).
} 
Table 1 Macroeconomic scenario 2021-2051

\begin{tabular}{lrrrr}
\hline & 2021 & 2031 & 2041 & 2051 \\
\hline Labor productivity (growth rate) & 2.7 & 1.9 & 1.7 & 1.7 \\
Participation rate (15-64) & 75.7 & 76.5 & 77.2 & 77.6 \\
Employment rate (15-64) & 71.0 & 71.8 & 72.4 & 72.8 \\
Unemployment rate (15-64) & 6.2 & 6.2 & 6.2 & 6.2 \\
\hline
\end{tabular}

Source: European Commission (2009b)

Individuals between 15 and 64 years of age can be in five possible situations during their working life: working as an employee, be self-employed, ${ }^{17}$ unemployed, receiving disability benefits or be in another situation of inactivity, ${ }^{18}$ such as being in education. Between the ages of 66 and 99, it is assumed that individuals are retired, with or without the right to receive a pension, according to the rules determined by law.

We have defined 120 different groups of individuals (12 groups divided by gender, education and nationality, and 10 by age between 15 and 64) whose contributions to the system and their pensions upon retirement we simulate. To reconstruct complete working histories we use real work histories from when they started working gathered from MCVL data.

Using the micro data obtained from the Labour Force Survey we calculated transition probabilities for the five possible situations between ages 15 and 64 in each time period of the life cycle according to age, gender, skill and nationality. Then, we estimated the probability of each of the five work situations conditional on the situation in the previous period using a Monte Carlo simulation. The estimation process follows a finite Markov chain that is, for the set of individual characteristics, homogeneous across workers and the corresponding conditional transition probability matrix. ${ }^{19}$

The transition probabilities obtained are consistent with the situation observed for the base year and the expected trend of the average employment rate over the projection period. Therefore, the virtual future history is obtained by incorporating macroeconomic assumptions and the probability of being in one of the five labour situations, differentiating by age, gender, nationality and educational level, in order to calibrate the corresponding rates of activity, employment and unemployment for each of the different groups of individuals.

Finally, retirement patterns of individuals classified by gender, educational level and age are observed through MCVL data. Individuals can retire early (between the ages of 61 and 64) or at the ordinary age of 65 , differentiating them by gender and

\footnotetext{
17 This distinction enables us to apply the characteristics of each scheme regarding retirement, for example in the special scheme for self-employed (Régimen Especial de Trabajadores Autónomos, RETA) early retirement is not allowed. In Spain, there are several contribution schemes organised by different sectors, but we assume the full integration of regimes into two main groups in the future: one for those employed within the General Regime (Régimen General, RG) and other for self-employed individuals contributing under the Special Scheme for Self-Employed (Régimen Especial de Trabajadores Autónomos, RETA), as recommended by the Toledo Pact Commission but not yet implemented.

18 Including the situation of inactivity is relevant because there are differences by gender, educational level and nationality as shown in González (2013).

19 See, González (2013) for further details.
} 
level of education. It is important to point out that we do not model the endogenous behavioral reactions of individuals to developments in the economic and legal environment; however, we gain in the microeconomic precision and data reliability of our simulations carrying out the computational exercise at the highest disaggregated level.

STAGE 3: Revenues and expenditures projection The model projects the work histories of the individuals (according to age, gender, skill and nationality) and their contributions to the system. It follows the assumed growth rate of wages (which corresponds to the growth rate of productivity from a macroeconomic scenario). The total revenue is equal to the sum of employed, self-employed and unemployed contributions $^{20}$ [for further details see González (2013)]. Once the work histories of each of the 12 different groups (by age, gender, skill and nationality) are obtained, we have the key elements to calculate the corresponding retirement pensions: (1) number of years of contributions, (2) wages (i.e. the contribution base) and (3) retirement age. The average pension benefit for each group is then calculated using these records and by applying the legislation. ${ }^{21}$ Pension expenditure takes into account pensions at 65 and early retirement between 61 and 64 . The total expenditure of the system is the sum of expenditure on retirement, widow's and disability pensions. ${ }^{22}$

\subsection{Impact on individual pensions}

The first noticeable effects of different increases in the maximum pension and the contribution limits would be an increase in the number of individuals whose pensions would have been capped. That is, in the future it is expected that new pensions will be higher, not only because wages will also be higher due to their growth in line with productivity, but also because individuals will have better work histories due to improvement of their education level. This is especially true for women, whose increased participation in the labour market, together with higher qualifications, will lead to higher pensions in the future. However, if the maximum pension value grew at a lower rate than productivity and the maximum contribution base grew alongside productivity, it would mean that a greater number of pensions would be capped as time passes.

In this section, we will analyse the consequences of the widening of the gap between the maximum pension value and the maximum contribution base for different groups of individuals, bearing in mind that the level of heterogeneity of the model is very high since individuals are classified according to their age, sex, educational level and nationality. The analysis in this section will focus on employed people (General Regime) who retire at 65 because it is the most affected group by this sort of reform. Moreover, our model also allows for the observation of what happens with early retirement (age 61-64) and the self-employed. Details about these groups are included in Appendix B.

\footnotetext{
20 Given the configuration of the Spanish system, a person receiving unemployment benefit generates rights for retirement through the contribution.

21 See Appendix A for more details about the rules on retirement in Spain.

22 See González (2013) for more detail about survivor's and disability pensions.
} 


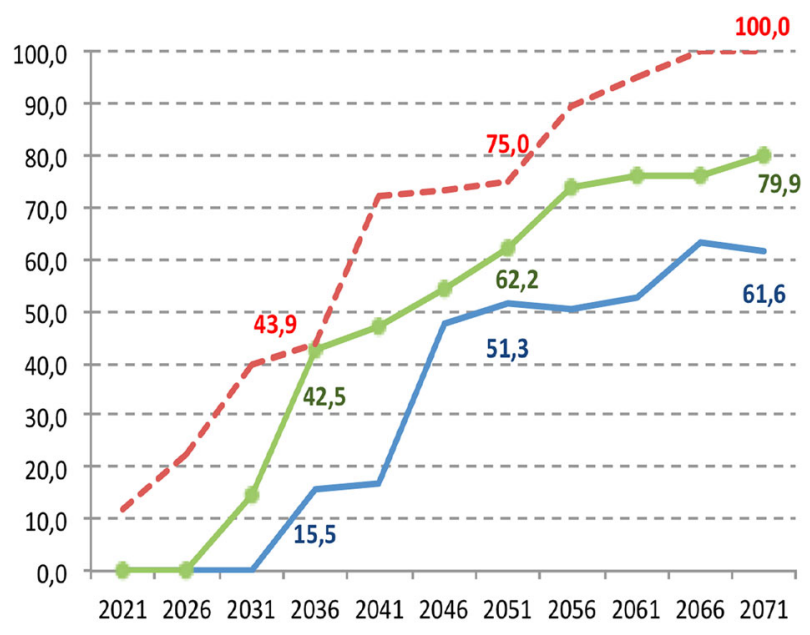

Scenario $2(1,0.5)-$ Scenario $3(1,0.3)--$ Scenario $4(1,0)$

Fig. 4 Percentage of new capped pensions. Scenario comparison (2021-2071)

The impact on the percentage of new pensions that are limited by the upper cap varies from scenario to scenario, as shown in Fig. 4. The effects start to be evident in 2036 in scenario 2 [or scenario $(1,0.5)$ ], in 2031 in scenario 3 [or scenario (1, $0.3)$ ], and in 2021 in scenario 4 or extreme scenario. In Fig. 4, we show the projected trend of percentage of pensioners affected in the coming decades. By 2051, $51 \%$ of new pensions would be capped in scenario 2, while in the most extreme scenario this proportion rises to $75 \%$. In this case, scenario 4, the effects would begin in 2021 and the percentage of capped pensions would rise over time exceeding $70 \%$ by 2051 and reaching $100 \%$ in 2071.

As we said before, if we have considered a scenario with a lower productivity growth rate, the effects of the 'silent reform' would be minor. In the case of the new capped pensions, the percentage in the extreme case would be 12.8 points lower in 2050, that is a $62.2 \%$ of total retirement pensions (see Fig. 9a in the Appendix C).

In a more detailed analysis, included in Table 2, men would be affected more than women by the mechanism described in Sect. 2.1 in every scenario. If we take the educational level into account, university graduates would have the highest percentage of limited pensions. This is to be expected, as graduates have a more complete work history and earn higher wages. There are also differences between the categories for men and women. However, women's pensions would be generally less affected, although those with higher qualifications would see their pensions capped. From 2041, the percentage of women with a university degree and capped pension benefit is higher than for their male equivalents. This is due to improved educational and work histories than their older counterparts.

Once we have obtained the percentages of new pensions affected, it is interesting to evaluate their impact on what the average pension is worth. Since a higher percentage of capped pensions are to be expected than in the neutral scenario, it is therefore also expected that this sort of reform would reduce the value of the average pension of the 
Table 2 Percentage of new capped pensions by scenario, gender and skill

\begin{tabular}{|c|c|c|c|c|c|c|c|c|c|}
\hline & \multicolumn{3}{|c|}{ Scenario $2(1,0.5)$} & \multicolumn{3}{|c|}{ Scenario $3(1,0.3)$} & \multicolumn{3}{|c|}{ Scenario $4(1,0)$} \\
\hline & 2021 & 2051 & 2071 & 2021 & 2051 & 2071 & 2021 & 2051 & 2071 \\
\hline \multicolumn{10}{|l|}{ Male } \\
\hline Primary & 0.0 & 0.0 & 0.0 & 0.0 & 0.0 & 24.7 & 0.0 & 25.8 & 34.7 \\
\hline Secondary & 0.0 & 16.6 & 15.9 & 0.0 & 16.6 & 15.9 & 0.0 & 16.6 & 25.9 \\
\hline Tertiary & 0.0 & 40.4 & 39.4 & 0.0 & 40.4 & 39.4 & 22.8 & 40.4 & 39.4 \\
\hline Total & 0.0 & 57.0 & 55.3 & 0.0 & 57.0 & 80.0 & 22.8 & 82.8 & 100.0 \\
\hline \multicolumn{10}{|l|}{ Female } \\
\hline Primary & 0.0 & 0.0 & 0.0 & 0.0 & 0.0 & 12.4 & 0.0 & 0.0 & 23.5 \\
\hline Secondary & 0.0 & 0.0 & 13.1 & 0.0 & 13.1 & 13.1 & 0.0 & 13.1 & 22.2 \\
\hline Tertiary & 0.0 & 45.7 & 54.3 & 0.0 & 54.2 & 54.3 & 0.0 & 54.2 & 54.3 \\
\hline Total & 0.0 & 45.7 & 67.4 & 0.0 & 67.3 & 79.8 & 0.0 & 67.3 & 100.0 \\
\hline
\end{tabular}

Table 3 Variation of the average new pension value in each scenario against the neutral one (\%,2021-2071)

\begin{tabular}{lccc}
\hline Year & Scenario $2(1,0.5)$ & Scenario 3 $(1,0.3)$ & Scenario 4 $(1,0)$ \\
\hline 2021 & 0.0 & 0.0 & 0.0 \\
2031 & 0.0 & -1.3 & -6.3 \\
2041 & -1.9 & -8.5 & -19.3 \\
2051 & -6.7 & -15.6 & -30.9 \\
2061 & -11.1 & -23.3 & -40.6 \\
2071 & -15.5 & -29.4 & -49.0 \\
\hline
\end{tabular}

system. For example, within four decades, the value of new pensions could be between 6.7 and $30.9 \%$ lower than the benefit recognized in the neutral scenario (see Table 3 ).

Following the individual details of the model, the value of pensions would decrease more for men than for women in any of the proposed scenarios (Table 7 in Appendix B). This is because men have higher contribution bases than women for any given level of education. Furthermore, if we take skill into account in the case of the extreme scenario, the resulting pensions could register a $44 \%$ reduction in their quantity by 2051. In the case of university graduates, there is nearly a $60 \%$ loss by 2071 (see Table 8 in Appendix B).

If we consider the scenario with a lower labor productivity growth rate, in 2050 the decrease in the average new pension value would be halved (in the case of the scenario 4) with a reduction of a $16.3 \%$ instead of a $30.9 \%$ (see Fig. 9b in Appendix C).

In Table 4, we compare the potential results of a pension reform as the analysed in this article with the reform of the Spanish pension system approved in $2011^{23}$ in order to assess its potential. It is clear that the effects on the average pension are very similar to those obtained under scenario 2 or $(1,0.5)$.

23 See Appendix A for further details of changes under this reform. 
Table 4 Variation of the average new pension value by scenario. Comparison with 2011 reform (year 2051)

\begin{tabular}{lcccc}
\hline & Scenario 2 $(1,0.5)$ & Scenario 3 $(1,0.3)$ & Scenario 4 $(1,0)$ & $\begin{array}{l}\text { Reform 2011 } \\
\text { (Conde-Ruiz and } \\
\text { González 2013) }\end{array}$ \\
\hline Total & -6.7 & -15.6 & -30.9 & -9.1 \\
Gender & & & & \\
Male & -8.8 & -17.8 & -33.4 & -8.1 \\
Female & -4.3 & -13.2 & -28.0 & -10.1 \\
Skill & & & & \\
Primary & 0.0 & 0.0 & -11.7 & -11.5 \\
Secondary & -3.5 & -10.1 & -24.3 & -11.1 \\
Tertiary & -10.3 & -23.4 & -40.4 & -7.4 \\
\hline
\end{tabular}

\subsection{Impact on sustainability}

In this section, we will analyse the potential implications that changes in the pension system such as those described in this paper would have on the evolution of total pension expenditure based on the different scenarios presented. As described in Sect. 3.1, we obtained the work histories and key elements necessary to calculate retirement pensions (number of years of contributions, contribution bases and retirement age). Then, we calculated the corresponding average pension for each group and applied the corresponding legislation. Total pension expenditure includes retirement pensions at 65 and early retirement between 61 and 64, taking into account both retirees under the employees or General Regime (Régimen General, RG) and under the special scheme for self-employed (Régimen Especial de Trabajadores Autónomos, RETA). As we have indicated, we will obtain the results based on the Spanish pension system prior to the 2011 reform for comparison.

As expected, the total pension expenditure will increase in the coming decades, not only due to higher life expectancy but also due to the fact that pensions will be higher because of the improvement of work histories. However, if the maximum contribution cap grows at the same rate as productivity and the upper pension limit remains constant in real terms (our extreme scenario), the value of the new pensions will be limited, as shown in the previous section, which would have implications in terms of the total pension expenditure. The difference between the neutral and the extreme scenarios would be perceptible from 2031 onwards because there would be a significant number of retirees at 65 entitled to the maximum pension. In fact, population dynamics plays an important role since, as seen in Fig. 5, the maximum number of new pensions is reached in 2040, when larger numbers of people (those from the baby boom) would retire and the trend of pension expenditure a percentage of GDP would adopt an inverted ' $U$ ' shape. At the same time, under the extreme scenario, pension expenditure for new pensions would continue to increase until 2046. From that point onwards there would be a two-fold effect: the number of new retirement pensions at 65 would be lower due to population dynamics, and the type of reform analysed would have its greatest impact in 2046. 


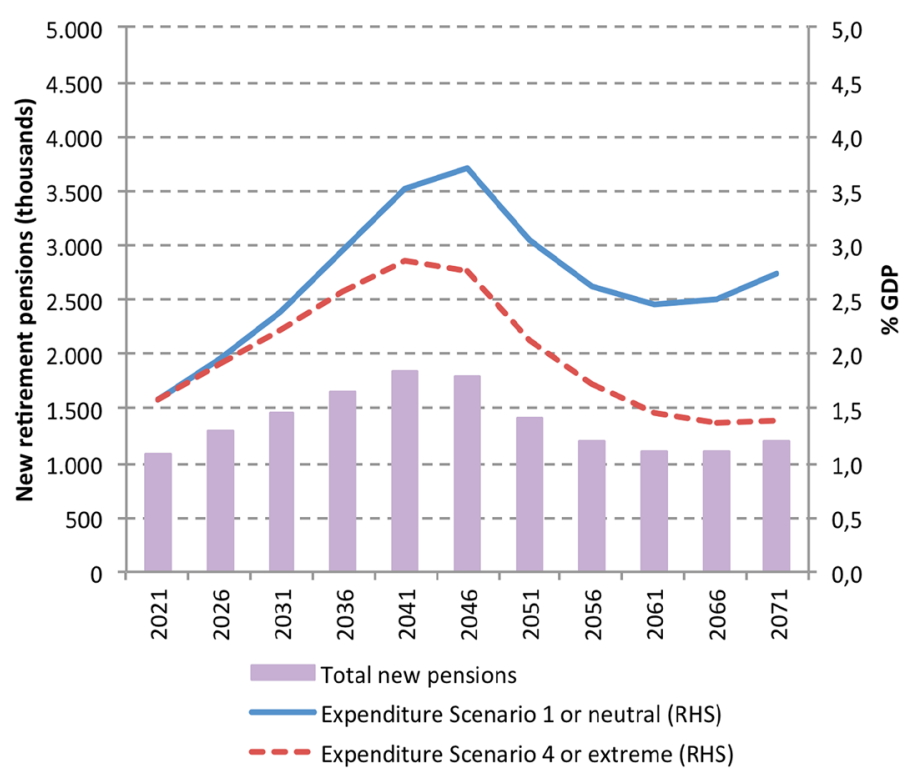

Fig. 5 New retirement pensions at 65 and expenditure: extreme and neutral scenarios (2021-2071)

If the characteristics mentioned were to remain constant over time, pension expenditure would be lower. Total expenditure would be lower if the scenario were closer to the extreme scenario, and it could reach, in comparison with neutral scenario, 3.2 percentage points (p.p.) of GDP by the year 2051 (see Table 5). The reason for this is obvious: in our model all wages grow in line with productivity and this means that all contribution bases (including the maximum) also grow at this rate. This implies that the Reference Wage (Base Reguladora) also grows for all individuals, which in turn generates the growth of benefit amount. Due to the fact that pensions have a maximum limit, a greater number of workers are entitled to the maximum pension. The higher the percentage of workers with a maximum pension, the lower the expenditure of the system. Moreover, if the maximum pension increase is 30 [scenario 3 or $(1,0.3)$ ] or 50 [scenario 2 or $(1,0.5)$ ] \% of productivity growth, then expenditure would be lower from 2041 onwards and, by 2051, it would be down 1.4 p.p. of GDP in scenario 3 and 0.4 p.p. of GDP in scenario 2.

Therefore, if the Spanish Pension System were to shift towards a Beveridgean one along the lines of the mechanism described in Sect. 2, there would be a significant effect on containing pension expenditure. As seen in this paper, it could lead to a 3.2 p.p. of the GDP reduction of expenditure by 2051 (Table 5) in an extreme scenario, compared with the 3.7 p.p. of GDP reduction under the 2011 reform, based on the same methodology and the same demographic scenario as in Conde-Ruiz and González (2013). ${ }^{24}$

\footnotetext{
24 We have focused the analyses on the mechanism of the 'silent reform' when the maximum pension benefit grows at a lower rate than the maximum contribution base and the minimum pension benefit grows at the same rate as productivity. If we assume an alternative scenario where the minimum pension remains constant in real terms, then the effects over future expenditure would be more pronounced, as can be seen in Conde-Ruiz and González (2016).
} 
Table 5 Total pension expenditure and reduction by scenario (2021-2071)

\begin{tabular}{lllll}
\hline \multirow{2}{*}{ Year } & Expenditure (\% GDP) & \multicolumn{3}{l}{ Reduction (p.p. GDP) } \\
\cline { 3 - 5 } & Scenario 1 (neutral) & Scenario 2 $(1,0.5)$ & Scenario 3 $(1,0.3)$ & Scenario 4 $(1,0)$ \\
\hline 2021 & 9.2 & 0.0 & 0.0 & 0.0 \\
2031 & 13.4 & 0.0 & 0.0 & -0.2 \\
2041 & 20.1 & -0.1 & -0.5 & -1.3 \\
2051 & 24.3 & -0.4 & -1.4 & -3.2 \\
2061 & 22.9 & -0.8 & -2.2 & -4.7 \\
2071 & 21.4 & -1.5 & -3.3 & -6.1 \\
\hline
\end{tabular}

Again, the labor productivity growth rate plays a crucial role on the impact of the 'silent reform'. In the scenario with a lower productivity growth rate, the impact over total pension expenditure over GDP (in the case of the scenario 4 or extreme scenario) is reduced a $40 \%$. Specifically, it could lead (in scenario 4) to a 1.4 p.p. of the GDP reduction of expenditure by 2051 (see Fig. 9c in the Appendix C).

If we analyse the revenue of the social security system as a percentage of GDP, it is easy to understand that, if all the contribution bases (including the maximum contribution base) grow at the same rate as worker productivity (i.e. scenario 1), total contributions will remain constant over time. However, it is also possible that an additional impact of the reform described previously could arise if we consider different scenarios where the maximum contribution base ${ }^{25}$ would grow at a higher rate than productivity. In this sense, we have considered two alternative scenarios: one where the maximum contribution base grows at 1.5 times the productivity growth rate and a second scenario where it grows at twice the productivity growth rate. As can be seen in Fig. 6, the impact on social security revenues could be significant, while in the second case it could imply an increase of around 3 percentage points of GDP by the year 2061.

\subsection{Implications for the nature of the system: from Bismarck to Beveridge}

If the process set out in this paper were to adopted, i.e. that the maximum contribution cap grows at the same pace as productivity and the upper benefit cap remains constant in real terms, it would have a significant effect on pension expenditure. However, it would also take place at a cost, since it would have important distributional consequences. Regarding the generosity of the system (defined as the ratio between average pension and productivity), ${ }^{26}$ the maximum would be reached in 2051 in all scenarios, but in the more extreme scenario there would be a lower level of generosity across the system. Within four decades, generosity would be the $24.2 \%$ in scenario $2,23.2 \%$ in scenario

\footnotetext{
25 According to data from the Continuous Sample of Working Histories of Social Security, the percentage of workers in Spain with the maximum contribution base would be around a 10-15\%. Cuadrado et al. (2011) and Bonhomme and Hospido (2012) observed that the 10th percentile of female earnings distribution is capped, rising to nearly $20 \%$ for male earnings.

26 The ratio of total pension expenditure to GDP can be decomposed as a function of three main components: demographics, the labour market and the institutional factor. The following equation illustrates the role
} 


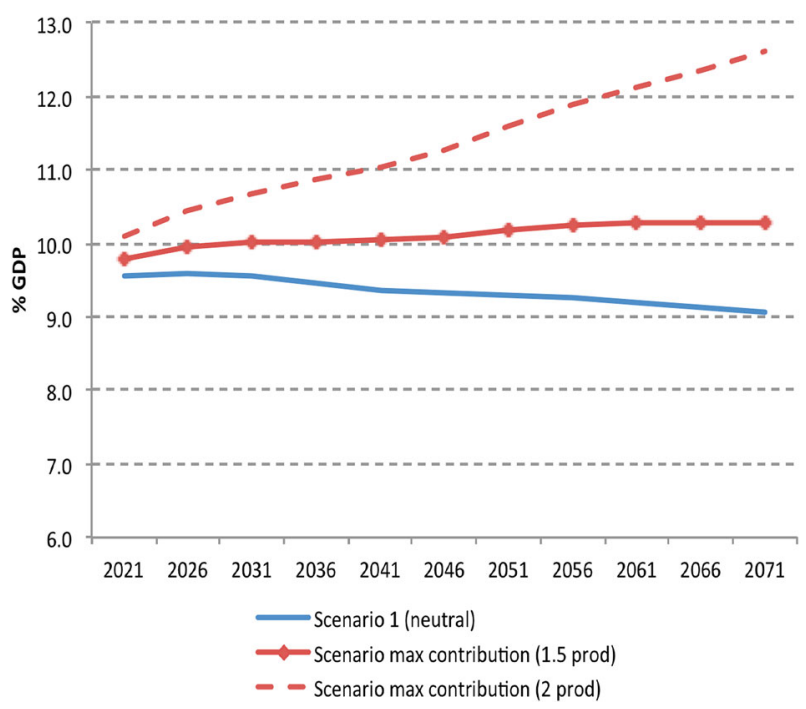

Fig. 6 Revenues under different maximum contribution growth rates (2021-2071)

3 and $21.2 \%$ in scenario 4 or extreme, versus $24.6 \%$ in a neutral scenario (Table 9 in Appendix B). Generosity would decline over time in all scenarios from 2051 onwards, when the number of pensioners affected increases, and would be most pronounced in the extreme scenario (see Fig. 7). This sort of pension reform could become a powerful mechanism to avoid the transfer of growth in productivity to pensions. Note that if no such changes were made, growth in productivity would transfer to the contribution bases (or wages), then to the Reference Wages, and finally to pensions.

The impact over the generosity would be a reduction of 3.2 points if we consider the scenario with a lower labor productivity growth rate. In this case the ratio of the average pension to productivity would be $24.4 \%$ in 2051 (see Fig. 9d in the Appendix C).

The ratio between pension value and contribution base can provide an insight into what would happen to the nature of the system under the type of reform analysed in this article. It is known as replacement ratio because it highlights the relation between an individual's pension and their last wage. If the pension system is purely contributory or Bismarckian, this ratio remains roughly constant in line with contributions. This implies that if someone has a higher salary (i.e. a higher contribution base), he will contribute more overall and will be entitled to receive a higher pension. As observed in Fig. 8, the ratio is maintained nearly constant in the neutral scenario. In the case of

Footnote 26 continued

generosity plays in the institutional factor and so on in the total expenditure as percentage of GDP.

$\frac{\text { Pension Expenditure }}{G D P}=\underbrace{\frac{\text { Pop. }>65 \text { years old }}{\text { Working Age Pop. }}}_{\text {Demographic Factor }} \cdot \underbrace{\frac{1}{\text { Employment Rate }}}_{\text {Labor Market Factor }} \cdot \underbrace{\frac{\overbrace{\text { Number of pensions }}^{\text {Elegibility }}}{\text { Pop. }>65 \text { years old }} \cdot \underbrace{\text { Generosity }}_{\frac{\text { Average Pension }}{\text { Average Productivity }}}}_{\text {Institutional Factor }}$




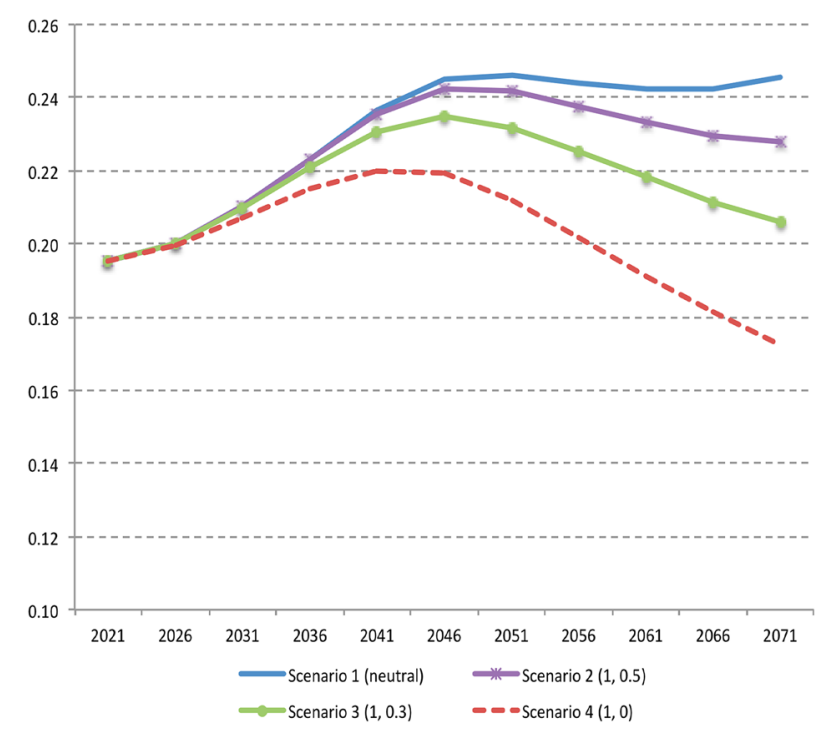

Fig. 7 Ratio of average pension to productivity (2021-2071)

female university graduates the replacement rate increases slightly due to the fact that they have more complete work histories, therefore gaining access to higher pensions.

In a Beveridgean (or pure redistributive pension system) pensions do not depend on contributions to the system. As stated previously, in a system of this type, the replacement rate decreases with respect to wages because all individuals receive the same pension regardless of their salary. Therefore, workers with higher wages have a lower replacement rate. This is precisely the result of maintaining the maximum pension value constant in real terms, while the maximum contribution base increases at the same pace as productivity. Figures $8 \mathrm{a}$, b show these contrasts as reflected in our extreme scenario for Spanish individuals retiring at 65, in which the replacement rate would decrease alongside the level of education.

The results obtained in this article prove that it would be possible to change the nature of the system from a contributive or Bismarckian type to a Beveridgean one. The kind of reform analysed in this paper would increase the intragenerational redistribution element in the pension system. This means that apparently small changes in some factors could lead to a significant structural reform that would completely change the nature of the system. ${ }^{27}$

Evidently, the reduction in the replacement rate alongside the level of education is less pronounced if we consider our scenario with lower productivity growth rate. This

\footnotetext{
27 This sort of reform also has implications in terms of the Internal Rate of Return (IRR). Following the methodology described in Jimeno and Licandro (1999) and Devesa Carpio et al. (2002) we have calculated the IRR for employed people (General Regime) who retire at 65. If the extreme scenario or scenario 4 took place, individuals in this group would have $3.4 \%$ IRR as opposed to $4.4 \%$ in the base scenario for the year 2051. It is noteworthy that this reduction would affect men and women differently. Men would have 2.9 $\%$ IRR in the extreme scenario and $4.0 \%$ in the neutral scenario; meanwhile, women would have $3.9 \%$ IRR instead of $4.7 \%$. Educational background is also a factor and those at higher levels would be the most affected.
} 


\section{(a) Male}

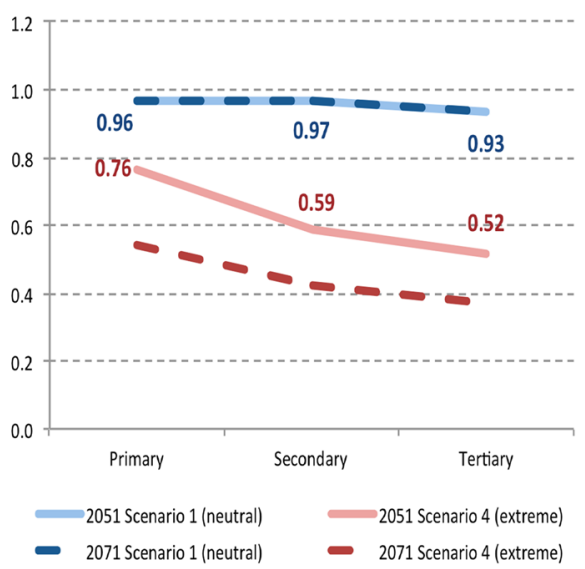

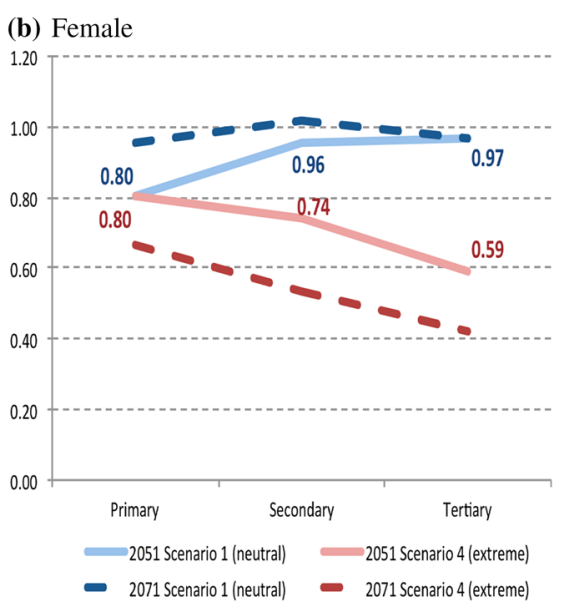

Fig. 8 Ratio first pension to last contribution base. Neutral and extreme scenario by gender and educational level. Year 2051 and 2071

fact proves that the lower the labor productivity growth rate is, the slower the change in the nature of the pension system towards a Beveridgean type.

\section{Conclusions and discussion}

The Spanish social security system, as well as many other European ones, has to face the challenge that an ageing population presents. There is no doubt that the average replacement rate (RR) will decline due to ageing pressure. However, there are several ways this reduction could be achieved: either by decreasing the RR linearly and guaranteeing the contributory element of the system, or by reducing the RR only for high earning workers and increasing the redistributive component of the system. We have shown that a full implementation of the pension policy that has already been adopted by the Spanish current and previous governments would result in the second option. This policy consists on increasing maximum pensions in line with inflation instead of wage or productivity growth. This paper explores the potential effects and implications of this theoretical idea and shows that it has relevant effects over the generosity of the pension system (by decreasing the ratio between the average pension and the average productivity) and its financial sustainability. We have shown that these changes could have significant effects on the expenditure of the system. In the most extreme case, it could imply a lower expenditure of 3.2 percentage points of GDP by 2051 and 6.1 p.p. of GDP by 2071. This impact is of great importance when compared to the effects of the 2011 pension reform. Conde-Ruiz and González (2013) demonstrated, using the same methodology and the same demographic scenario as in this article, that the 2011 reform (in which the calculation period was extended, retirement age was increased to 67 and a modified replacement rate was applied to the reference wage) may imply a 3.7 p.p. of GDP reduction of expenditure by 2051 .

As we have seen, different growth rates between the maximum pension benefit and the maximum contribution base constitute per se a potential powerful reform mechanism that also has distributional effects. The policy of indexing the maximum 
pension with inflation may seem harmless and may seem not to imply any institutional change to the pension system, at least in the early stages. However, it is not the case in a context of growing wages (in real terms), as we have shown in this paper. In particular, the application of this type of reform could imply, in an extreme scenario, an average retirement benefit reduction of $50 \%$ in the long term for workers with a tertiary education level. This means that it would reduce the average generosity of the pension system and would contribute its the financial sustainability.

However, given that this decrease in the average generosity of the system would be achieved by reducing only higher pensions, the reform also increases the degree of intragenerational redistribution of the system. Therefore, we have also shown that the reform could completely change the nature of the system, transforming it from a contributory or Bismarckian system into a pure redistributive or Beveridgean one.

This result is crucial as it opens the door to a possible reform of the pension system in Spain. The intensity of the ageing process will inevitably make the average replacement rate drop significantly. At the same time, widening income inequality has increased political support for lowering the replacement rate only for the highest pensions. Regarding this, it is important to point out that the Bismarckian system was originally created as a response to the demands of the middle class to provide a sufficient level of income in old age. Universal pensions in a pure redistributive system (i.e. Beveridgean) were created with the aim of providing a minimum pension equal for all workers, but leaving enough room for individuals to add to their pension packages with private savings. Both models already exist in Europe, and the only danger of this kind of change is not the change itself, but rather introducing it in a timely manner to give citizens enough time to adapt their decision-making regarding savings to the new pension system.

We have also seen that the labor productivity growth rate plays a crucial role on the impact of the 'silent reform'. In particular, the higher the growth rate is, the lower the effects over the sustainability, the level of the pensions and over the changes in the nature of the pension system.

The main limitation of our methodology is that we assume decisions made by the workers (retirement age or educational level) are exogenous. In other words, our simulations are subject to the 'Lucas critique' in the sense that we do not model endogenous behavioural reactions of workers to changes in the rules of the social security system and their effects over the relative prices. In this respect, our simulation does not take into account important implications. This simplification has allowed us to incorporate a very precise institutional detail of the Spanish pension system within the model, as well as a high level of individual heterogeneity amongst individuals.

We have seen that the 'silent reform' generates a strong reduction in the generosity of the pension system with a significant reduction of the replacement rates, and therefore individual decisions over retirement, savings and human capital investment must be affected. Individual retirement behavior is largely influenced by wealth or income effects. Several studies [see e.g. Costa (1998), Butler et al. (2005) and Euwals et al. (2010)] show that both expected and unexpected decrease in workers' income or wealth induce them to postpone retirement. At the same time, a reduction in the pension income combined with the increase in longevity, may induce individuals to save more, not only in physical capital, in order to accumulate assets for the retirement period [see e.g. Higgins (1998), Kelley and Schmidt (1996), Masson et al. (1998) and Bloom et al. 
(2003)], but also in human capital by training-on-the-job and by learning-by-doing, in order to remain active in the labor market for a longer period of time. In a nutshell, the reaction of the individuals to the reduction in pension generosity (i.e. delaying retirement, increase in private savings and more investment in human capital) will not only help them to adapt to the new demographic scenario, but will also reduce the problems of financial sustainability of the pension system.

Open Access This article is distributed under the terms of the Creative Commons Attribution 4.0 International License (http://creativecommons.org/licenses/by/4.0/), which permits unrestricted use, distribution, and reproduction in any medium, provided you give appropriate credit to the original author(s) and the source, provide a link to the Creative Commons license, and indicate if changes were made.

\section{Appendix A: Retirement in Spain}

The key factors for calculating retirement pensions in Spain, up to the application of the Sustainability Factor in year 2019, are: (1) eligibility, (2) number of qualifying years, (3) wages through contribution bases and (4) retirement age.

Eligibility depends on the number of years that contributions were made and on the age of retirement. Pensions are granted to individuals who have contributed to the system for at least 15 years, two of which must be within the last 15 years prior to retirement, who have reached the age of 65 (prior to the 2011 reform) and have retired from the active labour force. Early retirement can be taken from 61 to 64 by those individuals with a minimum period of contribution of 30 years and incurs a percentage reduction of the pension benefit. ${ }^{28}$ For eligible individuals, the Spanish system provides an old age pension benefit equal to: $p_{t}=\alpha \theta \widetilde{w}$, where $\widetilde{w}$ is the reference wage (Base Reguladora), $\theta$ is the replacement rate (percentage applied to the reference wage or Base Reguladora) and $\alpha$ is the penalty for early retirement. The reference wage represents the weighted average of contributions to social security over the 15 years prior to retirement (following the system before the 2011 pension reform), and where contributions made in the two years prior to retirement are indexed to inflation (Eq. 3).

$$
\widetilde{w}_{t}=\frac{\left(\sum_{i=1}^{24} b_{t-i}+\sum_{i=25}^{180} b_{t-i} \frac{C P I_{t-25}}{C P I_{t-i}}\right)}{210}
$$

where $b_{t}$ is the contribution base at time $t$ and $C P I_{t}$ represents the consumer price index at time $t$. The denominator is equal to 210 because it takes into account that the

\footnotetext{
${ }^{28}$ Prior to the 2011 reform, the two most relevant reforms took place in 1997 and 2002. In 1997, the number of years required to be entitled to a retirement pension was increased from 8 to 15 years with the corresponding timetable. Moreover, the period for calculating the reference wage was extended from 8 to 15 years and the replacement rate was established as $50 \%$ for the first 15 years of contributions. Each additional year up to year 25 adds $3 \%$ and from that year onwards, each additional year adds another $2 \%$ until reaching $100 \%$ for 35 years of contributions. Pensions have been indexed to inflation since this reform. Later, the 2002 reform allowed for early retirement at 61 for those workers that had not contributed before 1967 and had contributed a minimum of 30 years. Moreover, it also introduced changes to the penalization coefficient for early retirement and a premium for late retirement was introduced ( $2 \%$ per additional year beyond 35 years of contributions or qualifying years).
} 
Spanish social security pension pays pensions in 14 payments per year. ${ }^{29}$ This reference wage may not coincide with the actual wage, due to the existence of upper and lower caps for contributions. Moreover, a replacement rate is applied to the reference wage depending on the number of qualifying years. An individual who has reached the minimum of 15 qualifying years (or years of contributions) will receive a benefit equal to the $50 \%$ of the reference wage; for the next 10 years (up to year 25), each year will add a $3 \%$ to the replacement rate; between years 26 and 35, each year will contribute an additional $2 \%$. When the individual has contributed the maximum of 35 years, the replacement rate is equal to $100 \%$, and any further years of contribution have no marginal value for workers.

$$
\alpha=\left\{\begin{array}{ccc}
0 & \text { for } & N<15 \\
0.5+0.03(N-15) & \text { for } & 15 \leq N \leq 25 \\
0.8+0.02(N-25) & \text { for } & 25<N<35 \\
1 & \text { for } & N \geq 35
\end{array}\right.
$$

where $\mathrm{N}$ represents the qualifying years (or years of contributions). Finally, coefficient $\alpha$ relates pension benefits to retirement age according to the following formula:

$$
\alpha=\left\{\begin{array}{ccc}
0 & \text { for } & R<61 \\
1-\gamma(65-R) & \text { for } & 61 \leq R<65 \\
1 & \text { for } & R=65
\end{array}\right.
$$

where $R$ represents retirement age. The discount parameter $\gamma$ is equal to $8 \%$ for individuals with less than 30 qualifying years (or years of contributions) and between 7.5 and $6 \%$ for the rest depending on the number of qualifying years. The corresponding minimum $\left(p_{\min }\right)$ and maximum $\left(p_{\max }\right)$ limits will be applied to the resulting pension. Note that while the formulas for calculating retirement pensions are the same for employees (or General Regime, RG) and the special scheme for self-employed (Régimen Especial de Trabajadores Autónomos, RETA), early retirement is not possible under RETA.

The 2011 reform did not affect eligibility but introduced some changes to three key parameters including the replacement rate, the period of calculation and the retirement age, as well as establishing a transitional period until the year 2027 to reach the new values. The number of years required to reach $100 \%$ of the reference wage was increased from 35 to 37 years, changing the scale to a regular and proportional one from the minimum one of $50 \%$ at 15 years. The period of contributions is extended to the last 25 years (instead of 15 years) and the statutory retirement age is raised from 65 to 67 by 2027 (although workers who have contributed for at least 38.5 years will be entitled to a full pension at age 65). The reference wage after the 2011 reform is calculated as follows: ${ }^{30}$

\footnotetext{
29 Ley 24/1997, de Consolidación y racionalización del Sistema de Seguridad Social.

30 The Sustainability Factor in Law 5/2013 will link the initial pension to changes in life expectancy at age 67. Its application will begin in 2019 and it will be automatically reviewed every 5 years. In addition, the law established a new Pension Revaluation Index that is obtained taking into account the balance between the revenue and expenditure of the system. All pensions, including the minimum one, will be adjusted annually by this percentage with a floor of $0.25 \%$ and a cap based on Consumer Price Index growth plus $0.5 \%$.
} 


$$
\widetilde{w}_{t}=\frac{\left(\sum_{i=1}^{24} b_{t-i}+\sum_{i=25}^{300} b_{t-i} \frac{C P I_{t-25}}{C P I_{t-i}}\right)}{350}
$$

Retirement age There is a well known pattern: workers retire either at the first legally permitted age ${ }^{31}$ or at 65 , evidence for which is collected in papers such as JimenezMartin and Sanchez-Martin (2000), Boldrin et al. (2004) and Jimenez-Martin and Sanchez-Martin (2007). The model takes into account that individuals can retire early (between 61 and 64 years) or at the ordinary age of 65 if before the 2011 reform (or at the correspondent age after the reform), and be classified by gender and level of education. $^{32}$

Qualifying years The complete work histories show that workers who retire within four decades have, on average, longer work histories. A general increase in both the number of men and women in this category is observed, regardless of nationality. ${ }^{33}$

Total pension expenditure Pension value is calculated for each group at each point in time according to the corresponding law and taking into account the number of qualifying years (or years of contributions) and the retirement age. We then apply the corresponding floor $\left(p_{\min }\right)$ and ceiling $\left(p_{\max }\right)$ to the resulting amount. The formulae for calculating pensions are the same for employees (RG) and self-employed (RETA), although in the latter the possibility of early retirement is not allowed. Total expenditure for retirement pensions is the sum of pensions that take place at 65 and between 61 and 64.

\section{Appendix B: Detailed results}

See Tables 6, 7, 8 and 9 in Appendix B.

Table 6 Percentage of new capped pensions by regime and age of retirement. Extreme scenario (2021-71)

\begin{tabular}{|c|c|c|c|c|c|c|}
\hline \multirow[b]{2}{*}{ Year } & \multicolumn{5}{|c|}{ General regime } & \multirow{2}{*}{$\begin{array}{l}\text { Self-employment regime } \\
\text { Regime }\end{array}$} \\
\hline & 65 years & 64 years & 63 years & 62 years & 61 years & \\
\hline 2021 & 11.9 & 0.0 & 0.0 & 0.0 & 0.0 & 0.0 \\
\hline 2031 & 40.0 & 28.5 & 20.7 & 0.0 & 0.0 & 0.0 \\
\hline 2041 & 72.3 & 53.3 & 56.8 & 34.4 & 18.4 & 0.0 \\
\hline 2051 & 75.0 & 78.0 & 80.1 & 44.0 & 56.1 & 0.0 \\
\hline 2061 & 94.9 & 91.7 & 85.3 & 74.2 & 80.4 & 34.3 \\
\hline 2071 & 100.0 & 100.0 & 96.6 & 70.1 & 74.2 & 68.6 \\
\hline
\end{tabular}

31 Early retirement at 60 in Spain was only possible for those who had made contributions before 1967 (the number of these cohorts are currently reducing due to aging). In 2001, the minimum retirement age was set at 61 .

32 See González (2013) for more details on retirement patterns in Spain.

33 Native men would exceed 40 qualifying years regardless of educational level. Women with secondary education qualifications (high school and college graduate) would experience the largest increase, reflecting women's increased participation in the labour market. However, only for those with a university degree would the gap between both genders be reduced (see, González 2013). 
Table 7 Variation in new pensions value in the neutral scenario by gender (\%, 2021-2071)

\begin{tabular}{|c|c|c|c|c|c|c|}
\hline \multirow[b]{2}{*}{ Year } & \multicolumn{2}{|c|}{ Scenario $2(1,0.5)$} & \multicolumn{2}{|c|}{ Scenario $3(1,0.3)$} & \multicolumn{2}{|c|}{ Scenario $4(1,0)$} \\
\hline & Male & Female & Male & Female & Male & Female \\
\hline 2021 & 0.0 & 0.0 & 0.0 & 0.0 & 0.0 & 0.0 \\
\hline 2031 & 0.0 & 0.0 & -2.3 & 0.0 & -9.1 & -1.4 \\
\hline 2041 & -3.5 & 0.0 & -10.4 & -6.2 & -21.3 & -16.8 \\
\hline 2051 & -8.8 & -4.3 & -17.8 & -13.2 & -33.4 & -28.0 \\
\hline 2061 & -13.6 & -8.6 & -25.5 & -21.0 & -42.9 & -38.2 \\
\hline 2071 & -17.4 & -13.6 & -31.8 & -27.0 & -51.0 & -47.0 \\
\hline
\end{tabular}

Table 8 Variation in new pensions value in each scenario, by gender and level of education (\%)

\begin{tabular}{|c|c|c|c|c|c|c|c|c|c|}
\hline & \multicolumn{3}{|c|}{ Scenario $2(1,0.5)$} & \multicolumn{3}{|c|}{ Scenario $3(1,0.3)$} & \multicolumn{3}{|c|}{ Scenario $4(1,0)$} \\
\hline & 2021 & 2051 & 2071 & 2021 & 2051 & 2071 & 2021 & 2051 & 2071 \\
\hline \multicolumn{10}{|l|}{ Male } \\
\hline Primary & & 0.0 & 0.0 & 0.0 & 0.0 & -15.4 & 0.0 & -17.0 & -38.4 \\
\hline Secondary & & -6.0 & -16.3 & 0.0 & -16.9 & -28.3 & 0.0 & -30.3 & -47.7 \\
\hline Tertiary & & -15.1 & -28.0 & 0.0 & -28.1 & -43.0 & -0.2 & -44.0 & -59.9 \\
\hline \multicolumn{10}{|l|}{ Female } \\
\hline Primary & & 0.0 & 0.0 & 0.0 & 0.0 & -0.5 & 0.0 & 0.0 & -22.6 \\
\hline Secondary & & 0.0 & -4.4 & 0.0 & -0.2 & -17.7 & 0.0 & -15.7 & -39.9 \\
\hline Tertiary & & -6.4 & -19.8 & 0.0 & -19.5 & -36.5 & 0.0 & -37.4 & -55.3 \\
\hline
\end{tabular}

Table 9 Generosity (ratio average pension/productivity) of the system in each scenario (\%, 2021-2071)

\begin{tabular}{lllll}
\hline Year & Scenario 1 (neutral) & Scenario 2 $(1,0.5)$ & Scenario 3 $(1,0.3)$ & Scenario 4 $(1,0)$ \\
\hline 2021 & 19.5 & 19.5 & 19.5 & 19.5 \\
2031 & 21.0 & 21.0 & 21.0 & 20.7 \\
2041 & 23.6 & 23.5 & 23.0 & 22.0 \\
2051 & 24.6 & 24.2 & 23.2 & 21.2 \\
2061 & 24.2 & 23.3 & 21.8 & 19.1 \\
2071 & 24.5 & 22.8 & 20.6 & 17.2 \\
\hline
\end{tabular}

\section{Appendix C: Sensitivity analysis}

See Fig. 9 in Appendix C. 


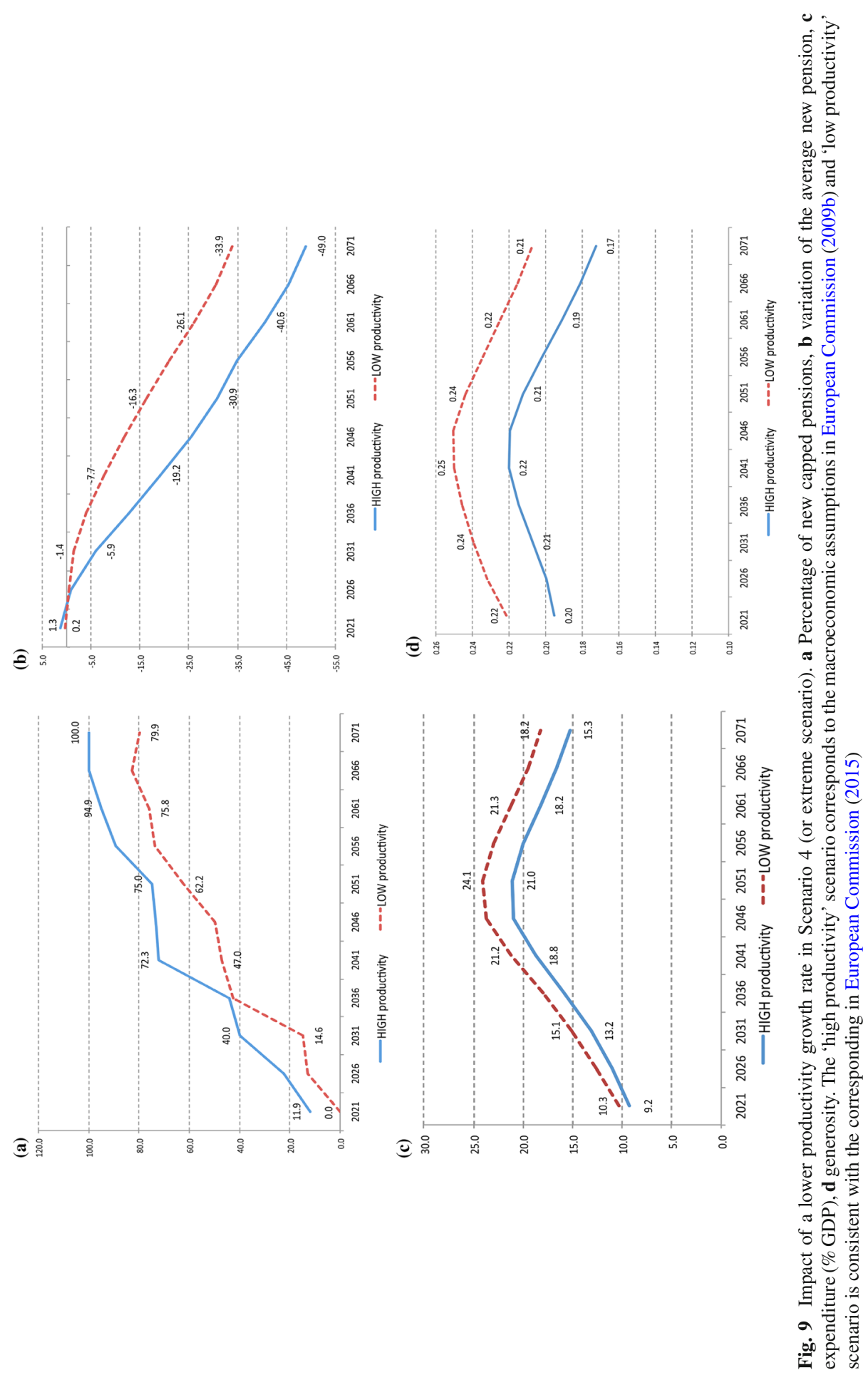




\section{References}

Alonso J, Herce J (2003) Balance del sistema de pensiones y boom migratorio en España Proyecciones del modelo MODPENS de FEDEA. Documento de Trabajo 2003-02, FEDEA

Argimón I, González CI (2006) La Muestra Continua de Vidas Laborales de la Seguridad Social. Boletín Económico Banco de España 5:39-53

Banco de España (2011) Informe Anual 2010. BdE, Madrid

Bloom D, Canning D, Graham B (2003) Longevity and life-cycle savings. Scand J Econ 105(3):319-338

Boldrin M, Jimenez S, Peracchi F (2000) Sistema de pensiones y mercado de trabajo en España. Fundación BBVA, Madrid

Boldrin M, Jimenez S, Peracchi F (2004) Micro-modelling of retirement behavior in spain. In: Gruber J (ed) Social security programs and retirement around the world: microestimation. University of Chicago Press for the NBER, Chicago

Bonhomme S, Hospido L (2012) The cycle of earnings inequality: evidence from spanish social security data. Working Papers 1225, Banco de España

Butler M, Huguenin O, Teppa F (2005) Why forcing people to save for retirement may backfire. Tech. rep., CESifo Working Paper Series

Conde-Ruiz JI, Alonso J (2004) El Futuro de las Pensiones en España: Perspectivas y Lecciones. Información Comercial Española ICE 815:155-174

Conde-Ruiz JI, González CI (2013) Reforma de pensiones 2011 en España. Hacienda Pública Española-204 (1/2013):9-44

Conde-Ruiz JI, González CI (2016) From Bismarck to Beveridge: the other pension reform in Spain. Studies on the Spanish Economy eee2016-16, FEDEA

Conde-Ruiz JI, Jimeno JF (2004) Suben las Pensiones? Fedea Brief

Conde-Ruiz JI, Profeta P (2007) The redistributive design of social security systems. Econ J 117(520):686712

Costa D (1998) The evolution of retirement. The evolution of retirement: an American Economic History, 1880-1990. University of Chicago Press, Chicago, pp 6-31

Cuadrado P, Hernández de Cos P, Izquierdo M (2011) El ajuste de los salarios frente a las perturbaciones en España. Boletín económico-Banco de España 2:43-56

de la Fuente A, Doménech R (2009) Spain and the Euro: the first ten years. Banco de España, chap Ageing and real convergence: challenges and proposals, pp 191-273

de la Fuente A, Doménech R (2013) The financial impact of Spanish pension reform: a quick estimate. J Pension Econ Fin 2:111-137

Devesa Carpio JE, Lejárraga García A, Vidal Meliá C (2002) El tanto de rendimiento de los sistemas de reparto. Rev Econ Apl 10(30):109-132

Diaz-Gimenez J, Diaz-Saavedra J (2006) The demographic and educational transitions and the sustainability of the Spanish Pension System. Moneda y Crédito 222:223-270

Diaz-Gimenez J, Diaz-Saavedra J (2009) Delaying retirement in Spain. Rev Econ Dyn 12(1):147-167

Diaz-Gimenez J, Diaz-Saavedra J (2014) The future of spanish pensions. Working Paper 14/03, Universidad de Granada

Diaz-Saavedra J (2005) A parametric reform of the Spanish public pension system. Universidad Carlos III de Madrid, Mimeo, Department of Business Administration

Disney R (2004) Are contributions to public pension programmes a tax on employment? Econ Policy 19(39):267-311

European Commission (2009a) The 2009 Ageing Report: economic and budgetary projections for the EU27 Member States (2008-2060). European economy 2/2009, European Commission (DG ECFIN) and Economic Policy Committee (AWG)

European Commission (2009b) The 2009 Ageing Report: underlying assumptions and projection methodologies. European economy 712008 European Commission (DG ECFIN) and Economic Policy Committee (AWG)

European Commission (2015) The Ageing Report 2015: economic and budgetary projections for the 28 EU Member States (2013-2060). European economy 312015, European Commission

Euwals R, van Vuuren D, Wolthoff R (2010) Early retirement behaviour in the netherlands: evidence from a policy reform. Economist 158(3):209-236 
Gil J, López García M, Onrubia J, Patxot C, Souto G (2008) SIPES, Un modelo de simulación del sistema de pensiones contributivas en España: proyecciones de gasto a largo plazo. Estudios de Hacienda Pública, Ministerio de Economía y Hacienda, Instituto de Estudios Fiscales

Gonzalez CI, Conde-Ruiz JI, Boldrin M (2009) Immigration and social security in Spain. Documento de Trabajo 2009-26, FEDEA

González CI (2013) Sostenibilidad del sistema de pensiones de reparto en España y modelización de los rendimientos financieros, Estudios de la Fundación. Serie Tesis, vol 65, FUNCAS

Herce J, Fernández (Dir) J (2009) Los retos socio-económicos del envejecimiento en españa. Informe realizado para UNESPA, AFI. http://www.unespa.es/adjuntos/fichero_3009_20100125.pdf

Higgins M (1998) Demography, national savings, and international capital flows. Int Econ Rev:343-369

INE (2005) Proyección de la Población de España a Largo Plazo, período 2002-2060. http://www.ine.es/ metodologia/t20/t2030251h.htm

Jimenez-Martin S, Sanchez-Martin A (2000) Incentivos y reglas de jubilación en España. Cuadernos económicos de ICE 65:45-88

Jimenez-Martin S, Sanchez-Martin A (2007) An evaluation on the life cycle effects of minimum pensions on retirement behavior. J Appl Econom 22:923-950

Jimeno JF (2002) Incentivos y desigualdad en el sistema español de pensiones contributivas de jubilación. Documento de Trabajo 2002-13, FEDEA

Jimeno JF (2003) La equidad intrageneracional de los sistemas de pensiones. Rev Econ Apl 33:5-48

Jimeno JF, Licandro O (1999) La tasa interna de rentabilidad y el equilibrio financiero del sistema español de pensiones de jubilación. Investig Econ 23(1):129-143

Jimeno JF, Rojas JA, Puente S (2008) Modelling the impact of aging on social security expenditures. Econ Model 25(2):201-224

Kelley AC, Schmidt RM (1996) Saving, dependency and development. J Popul Econ 9(4):365-386

Krieger T, Traub S (2013) The bismarckian factor: a measure of intra-generational redistribution in international pension systems. CESifo DICE Rep 1:64-66

Masson PR, Bayoumi T, Samiei H (1998) International evidence on the determinants of private saving. World Bank Econ Rev 12(3):483-501

MEH (2011) Programa de Estabilidad España 2011-2014. Ministerio de Economía y Hacienda. http:// www.meh.es

MINECO (2014) Actualización del Programa de Estabilidad España 2014-2017. Ministerio de Economía y Competitividad. http://www.mineco.gob.es

Moral-Arce I, Patxot C, Souto G (2008) La sostenibilidad del sistema de pensiones. Una aproximación a partir de la MCVL. Rev Econ Apl 16(E-1):29-66

MTIN (2008) Estrategia nacional de pensiones. Ministerio de Trabajo e Inmigración. http://www.mtin.es

OECD (2013) Public and private expenditure on pensions. In: OECD Factbook 2013. OECD Publishing

Rojas JA (2005) Life-cycle earnings, cohort size effects and social security: a quantitative exploration. J Public Econ 89(2-3):465-485

Sanchez-Martin A (2001) Endogenous retirement and public pension system reform in Spain. Economics Series 03-Working Paper 01-35, Universidad Carlos III, Departamento de Economía

Sanchez-Martin A (2010) Endogenous retirement and public pension system reform in Spain. Econ Model 27(1):336-349

Sanchez-Martin A (2014) The automatic adjustment of pension expenditures in Spain: an evaluation of the 2013's pension reform. Forthcoming Working Paper, Banco de España

Sanchez-Martin AR, Sanchez-Marcos V (2010) Demographic change and pension reform in Spain: an assessment in a two-earner. OLG Model. Fiscal Stud 31(3):405-452

Seguridad Social (2006) La Muestra Continua de Vidas Laborales, vol Colección informes y estudios. Serie Seguridad Social, num 24. Ministerio de Trabajo y Asuntos Sociales 